\title{
NEW ALIEN TAXA OF THE GENUS CORNUS (CORNACEAE) RECORDED IN LITHUANIA AND LATVIA
}

\author{
Zigmantas Gudžinskas*, Lukas Petrulaitis
}

Nature Research Centre, Institute of Botany, Žaliujų Ežerų Str. 49, 12200 Vilnius, Lithuania

*Corresponding author. E-mail: zigmantas.gudzinskas@gamtc.lt

\begin{abstract}
Gudžinskas Z., Petrulaitis L., 2021: New alien taxa of the genus Cornus (Cornaceae) recorded in Lithuania and Latvia. - Botanica, 27(2): 160-169.

Plants of the genus Cornus are valued for their ornamental qualities, are often grown in gardens, parks, or other public plantings, and form various shelterbelts. This increases the likelihood that these bird-dispersed plants will escape from their sites. This paper provides information on the first record of C. mas in Lithuania in 2021 at two sites. This species is currently considered a casual alien species, but may become locally naturalised in the future. This study confirmed that $C$. sericea is widespread in Lithuania, and the oldest herbarium specimen of the species was collected in 1997. Cornus sericea, like C. alba, is naturalised and potentially invasive in Lithuania. The alien subspecies of $C$. sanguinea (C. sanguinea subsp. australis) was found for the first time in Lithuania and Latvia in 2018. Available data show that this subspecies is naturalised in both countries, and its abundance in some areas in Lithuania indicates that it may become an invasive plant. The paper discusses dispersal vectors, occupied habitats, and the potential for spreading three alien Cornus taxa.
\end{abstract}

Keywords: casual species, dispersal, distribution, escaped species, habitats, naturalised species, naturalisation.

\section{INTRODUCTION}

In many European countries, as in many other parts of the world, the number of alien woody plants has increased rapidly in recent years (RICHARDSON et al., 2014; Nunez-Mir et al., 2019; Ferus et al., 2020; GREGOR \& KASPEREK, 2021). Many new species of escaped alien trees and shrubs are being discovered every year, some of which are already quite widespread and naturalised (VERLOOVE, 2011; GUDŽINSKAS et al., 2017; Ferus et al., 2020; MarazZi et al., 2021). There are several reasons for this phenomenon. Many woody plants were introduced in the mid-20th century for ornamental, forestry or other purposes and have since become widespread in ornamental plantations (KŘIVÁNEK \& PYŠEK, 2008; TAURA \& GUDŽINSKAS, 2020). Once widely cultivated in gardens, forests or other green spaces, these plants have begun to reproduce and spread spontaneously out- side of places of their cultivation (GUDŽINSKAs et al., 2017; Petrulaitis \& GudžInskas, 2020; Ferus et al., 2020). Another important reason is the ongoing climate changes, creating favourable conditions for the spread of woody plants that were previously restricted by less favourable climates (ZwIENER et al., 2018; FINCH et al., 2021).

Many species in the genus Cornus L. are valued for their distinctive ornamental or other qualities. They are widely grown in gardens and other plantings. At least 15 species of this genus are cultivated in the Baltic States (Navasaitis, 2008; Laiviñš et al., 2009). Some of the introduced Cornus species have been spreading and naturalising for quite a long time. In contrast, the spread of other species has only been observed in recent years (Petrulaitis \& GudžInSKas, 2020), and the number of escaped species of this genus will likely increase in the future.

The genus Cornus L. (Cornaceae Bercht. et J. Presl) 
has been represented in Lithuania by one native species, C. sanguinea L. (Lekavičıus, 1976; NAvasaitis et al., 2003), and several introduced species (LEKAVIČIUS, 1976; JANUŠKEVIČIUS et al., 2006; NAVASAITIS, 2008). However, subsequent surveys have shown that several introduced species of the genus Cornus ( $C$. alba L., C. alternifolia $\mathrm{L}$. and $C$. amomum Mill.) are spreading in the country as aliens (GUDŽINSKAS et al., 2017; Petrulaitis \& GudžInSKas, 2020). In Latvia, this genus is represented by two native, $C$. sanguinea and C. suecica L. (Chamaepericlymenum suecicum (L.) Asch. et Graebn.), and two alien, Cornus alba and C. sericea, species (Laiviñš et al., 2009; Priedītis, 2014). In addition, 12 other introduced species of this genus are cultivated in Latvia (LAIVIN̦Š et al., 2009).

The circumscription of the genus Cornus has been and still is the subject of scientific debates (EYDE, 1988; Murrell, 1993; Lindelof et al., 2020). Based on morphological characters, mainly the morphology of the bracts and fruits, Cornus has been divided into several segregate genera (MurReLl, 1993). WeAKLEY (2020) states that the genus Cornus, when treated very broadly, is monophyletic, but various clades within it are also monophyletic and can be recognised as distinct genera. Since there is no explicit treatment of the segregate genera, we accept the broad circumscription of the genus Cornus (XIANG et al., 2006; LiNDELOF et al., 2020).

The paper aims to provide information on three new alien taxa of the genus Cornus found in Lithuania and Latvia, estimate their populations' status, and assess the potential for their further spread and naturalisation.

\section{MATERIALS AND METHODS}

The paper is based on field surveys carried out in Lithuania in 2018-2021 and Latvia in 2018-2019. Herbarium specimens of Cornus taxa collected during this research were deposited at the Herbarium of the Institute of Botany of the Nature Research Centre (BILAS). In addition, the herbarium specimens of the genus Cornus stored at the Herbarium of the Institute of Botany were analysed. A list of herbarium specimens used to prepare this paper is given in the Appendix.

A distribution map of C. mas in Lithuania was compiled applying a system of grid cells, which were arranged according to geographical coordinates with sides of $6^{\prime}$ of latitude and 10' of longitude.

\section{RESULTS}

\section{Cornus mas}

Cornus mas L., Sp. Pl.: 117. 1753. - Cornus mascula L., Syst. Nat. ed. 10, 2: 897. 1759; Eukrania mascula (L.) Merr., Index Raf.: 184. 1949.

Cornus mas is a small tree, or more frequently a shrub, native to western and southern Europe and western Asia. Isolated autochthonous populations of C. mas outside of its continuous native range exist in Germany, the Czech Republic and Ukraine (CAudulLo et al., 2017). In addition, naturalised populations of this species have been recorded in the British Isles, Sweden, Norway (CAudullo et al., 2017) and North America (Ebinger \& McClain, 1997).

Escaped C. mas was found for the first time in Lithuania in 2021 in two localities (Fig. 1). The first group of this species was found on 8 August 2021 in Rokantiškès, Vilnius, and the second group was found on 6 September 2021 in Andruškoniai, Kaunas district.

In Vilnius, Rokantiškès, more than 50 C. mas individuals were found growing in a mixed anthropogenic woodland dominated by Betula pendula, Populus tremula and Picea abies. The individuals, varying in age and height from 1 to $3 \mathrm{~m}$, were scattered over a 0.11 ha woodland area. The size and condition of the plants suggest that some of the largest individuals are ten years old or even older. The woodland is quite dense (coverage of tree layers is about $60 \%$ ), so the Cornus mas individuals have not yet reached generative maturity. Considering that the individuals were quite variable in age, it can be assumed that they have grown over several years from seeds that were brought and discharged in the stand with tree leaves and other garden waste. The abundance of Vinca minor in the woodland also suggests that garden waste has been deposited here for many years.

In a long-abandoned meadow, a group of five Cornus mas individuals was found in Andruškoniai village (Kaunas district). All individuals were without fruits, but already had well-formed flower buds for the following year. Therefore, it is possible that the trees, which were approximately 7-10 years old and 2-2.5 m tall, were reaching maturity in 2021 . 


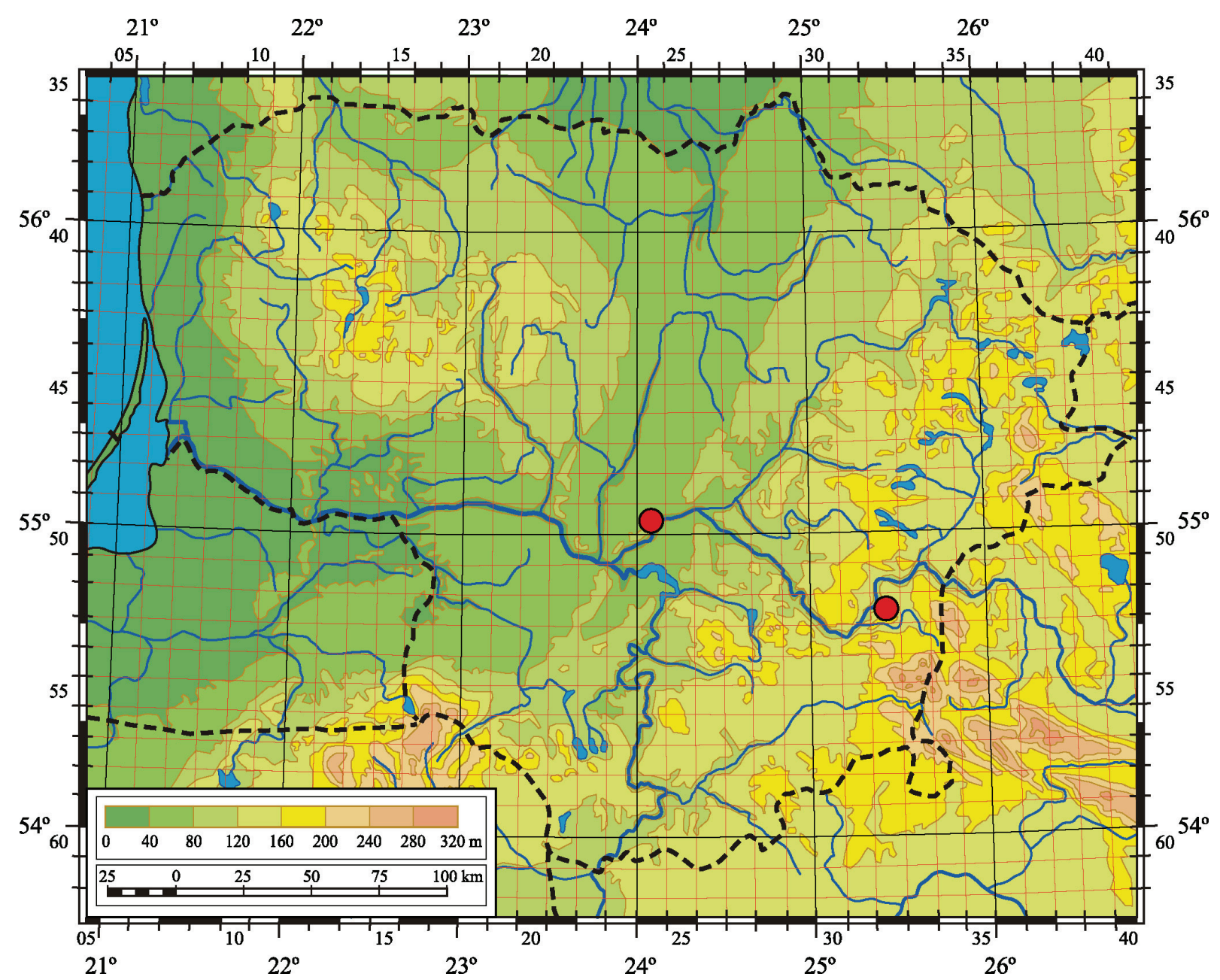

Fig. 1. Distribution of Cornus mas records in Lithuania (red dots)

Furthermore, all five individuals grow close to each other (10-25 cm apart), suggesting that they evolved from seeds discarded with garden waste.

Considering the current state of C. mas and the number of individuals in the recorded localities, it should be treated as a casual alien, though its naturalisation is probable. As C. mas is increasingly cultivated in gardens and plantations, it is likely to be found escaped in other parts of the country, particularly around urbanised areas.

\section{Cornus sanguinea subsp. australis}

Cornus sanguinea L. subsp. australis (C.A. Mey.) Jáv. in Sóo \& Jávorka, Magyar Növ. Kéz., 1: 398. 1951. - Cornus australis C.A. Mey., Bull. Cl. Phys.-Math. Acad. Imp. Sci. Saint-Pétersbourg, 3:
372. 1845; Swida australis (C.A. Mey.) Pojark. ex Grossh., Opred. Rast. Kavk.: 205. 1949; Thelycrania australis (C.A. Mey.) Sanadze, Trudy Tbilissk. Univ., 29a: 38. 1946.

Cornus sanguinea subsp. australis is a shrub or small tree native to south-eastern Europe and western Asia (Schulz, 2012). However, the status of this subspecies in Central Europe is not entirely clear. Some authors indicate that the northern limit of the native distribution runs through southern Poland (KAPLAN et al., 2019), but most consider this subspecies to be alien to most of Central Europe (Verloove, 2011; EssL et al., 2018; RiEbl et al., 2018; MAes \& van LoON, 2020; Gregor \& KASPEREK, 2021).

During field surveys in Vievis (Elektrènai district) in 2018, we were attracted by the unusually tall and highly fertile, tree-like individuals of $C$. sanguinea. 
Examination of the herbarium specimens collected in this area revealed that they belong to a distinct subspecies, C. sanguinea subsp. australis. Further investigations in the vicinity of Vievis showed that $C$. sanguinea subsp. australis is widespread and grows near the railway and in pine forests, along roadsides, on the slopes of drainage ditches, in abandoned grasslands and various anthropogenic habitats.

In surveys carried out in 2018-2019, C. sanguinea subsp. australis stands of various sizes in Ignalina (Dūkštas), Kaišiadorys (Kaišiadorys, Pravieniškès), Kaunas (Padauguva), Šiauliai (Drąsučiai, Ginkūnai), Švenčionys (Družiliai), Utena (Utena) and Vilnius (Dūkštas, Maišiagala, Sudervè) districts and in Šiauliai and Vilnius cities were also recorded. In Ginkūnai, Kaišiadorys, Šiauliai and Maišiagala, this subspecies is particularly widespread and exceptionally abundant, forming large, in some places pure or almost pure stands and invading natural, seminatural or anthropogenic habitats of woodlands, abandoned grasslands or wastelands. In some localities, espe- cially in Šiauliai, Kaišiadorys and Vievis and their surroundings, C. sanguinea subsp. australis forms large thickets under electric power lines (Fig. 2).

Examination of the herbarium specimens of C. sanguinea from Lithuania (BILAS) revealed that the oldest $C$. sanguinea subsp. australis was collected by P. Snarskis in 1940, on the western side of the narrow gauge railway line Panevėžys-Joniškèlis, ca. $4 \mathrm{~km}$ north of Bernatoniai railway station (now in Panevėžys district). As the railway was completed in 1938, we assume that $C$. sanguinea subsp. australis was planted in the railway protection belt, although P. Snarskis does not indicate this on the herbarium specimen label. Thus, this subspecies started to be cultivated in Lithuania in the first half of the 20th century.

On 1 September 2018, C. sanguinea subsp. australis was also found in Latvia, in the vicinity of Salaspils, in an abandoned cultivated grassland heavily invaded by Solidago canadensis L. Several $1.5-2.5 \mathrm{~m}$ tall individuals with ripe fruits were found

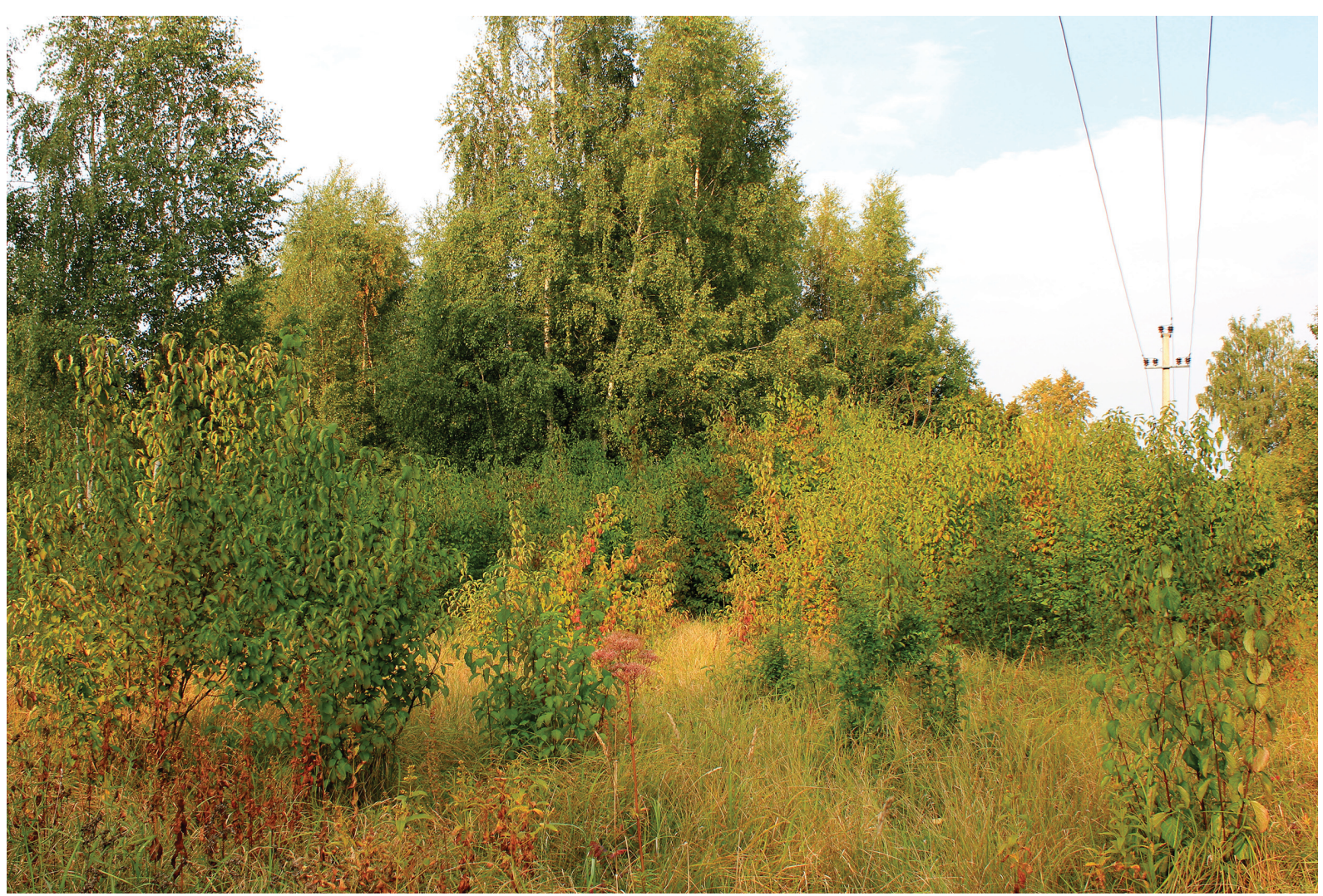

Fig. 2. Thickets of Cornus sanguinea subsp. australis under the electric power line in the environs of Šiauliai (2 September 2019) 
widely scattered throughout the grassland. We found Cornus sanguinea subsp. australis in Bauska (environs of Dālini village) and Tukums (the city's industrial district) municipalities in 2019. In the environs of Dālini village, quite extensive stands of $C$. sanguinea subsp. australis were found along the road and anthropogenic woodland, whereas in Tukums, solitary individuals occurred on the slope of a ditch and among shrubs near the railway line.

The current distribution and abundance of C. sanguinea subsp. australis in registered localities suggests a naturalised plant with apparent signs of invasiveness in Lithuania. In our opinion, C. sanguinea subsp. subsp. australis is also naturalised in Latvia, but we do not have sufficient data to assess its invasiveness.

\section{Cornus sericea}

Cornus sericea L., Mant. P1., 2: 199. 1771. - Swida sericea (L.) Holub, Folia Geobot. Phytotax., 2: 427. 1967; Thelycrania sericea (L.) Dandy, Watsonia, 4: 47. 1957; Cornus stolonifera Michx. in Fl. Bor.-Amer., 1: 92.1803.

Cornus sericea is native to North America, ranging from Alaska and Canada in the north to California and northern Mexico in the south (CHARLES-Dominique et al., 2010; Murrell \& Poindexter, 2016). Usually, it grows in wetlands, floodplains, grasslands, riparian habitats, and woodlands (CHARLES-DominIQUE et al., 2010). Although C. sericea well tolerates long-term flooding, it usually prefers mesic sites and nutrient-rich soil (ACHARYA et al., 1992). In Europe, C. sericea started spreading in the second half of the 19th century (Kelly, 1990; Kowarik, 1995; PYšEK et al., 2002; MedveckÁ et al., 2012). It is now naturalised in many countries and is considered a potentially invasive species in some Central European countries (BAČIČ et al., 2015; TYLER et al., 2015).

The information that $C$. sericea sometimes occurs escaped from cultivation in Lithuania was first reported by LeKAVIČIUs (1976), but herbarium specimens confirming this statement were not found among the herbarium collections. Previously, we had assumed that $C$. sericea belonged to the $C$. alba L. s.l. group (GUDŽINSKAS et al., 2017), but recent studies have shown that the two taxa are related, but quite distinct species (Xiang et al., 2006; Murrell \& Poindexter, 2016; LiNDELOF et al., 2020).
Examination of the specimens in the herbarium collections revealed that $C$. sericea was first collected as an escaped species in Lithuania in 1997. The plants were collected in a reedbed in the present-day Žuvintas Biosphere Reserve, at the shore of Lake Žuvintas (Alytus district).

In the populations of $C$. sericea observed in Lithuania, individuals with the characteristic dark purple bark predominate, but some plants with green or yellowish-brown bark are also quite common. Populations dominated by individuals with green or yellowish-brown bark, or populations composed exclusively of such individuals, are rare.

Recent surveys show that $C$. sericea is widespread in Lithuania and common in some regions, forming large stands. The spread of $C$. sericea is of particular concern as this species frequently invades various types of wetland habitats, including swampy deciduous forests. Cornus sericea, like C. alba, is naturalised in Lithuania and shows many signs of invasiveness. Therefore, it is necessary to accurately assess their environmental impact and stop the further spread and possible adverse effects on particularly valuable wetland habitats.

\section{DISCUSSION}

The discovery of new alien taxa of the genus Cornus in Lithuania was not unexpected. Many introduced plant species that have been extensively and continuously cultivated in gardens and other planting areas sooner or later start spreading if they produce seeds or can reproduce vegetatively (PERGL et al., 2016).

Cornus mas has long been widely cultivated for its fruit and ornamental qualities (CAudullo et al., 2017) and is increasingly being grown in gardens in temperate regions, including Lithuania (NAVASAITIS, 2008; LAIVIN̦Š et al., 2009). Despite its long history of cultivation, C. mas is relatively rarely found as an alien plant. Naturalised populations of this species have been recorded in the British Isles, Sweden, Norway (CAudullo et al., 2017) and North America (EBInger \& McClain, 1997). It should be noted that C. mas is considered a non-invasive species in all countries where it is naturalised (EBINGER \& McClaIN, 1997; GederaAs et al., 2012; CAudullo et al., 2017). The climatic conditions in Lithuania are favourable for 
C. mas naturalisation. Nevertheless, we believe that there is almost no chance of this plant ever becoming widespread and invasive in the country. Therefore, the highly ornamental C. mas could be used more extensively in urban and village landscaping.

Cornus sanguinea is a native species in Lithuania and Latvia (LeKavičius, 1976; Priedītis, 2014), easily distinguishable from other Cornus species. As a result, specialists occasionally collect its herbarium specimens and even less frequently identify them by detailed examination of all morphological characters. Thus, the spread of the alien subspecies $C$. sanguinea subsp. australis in the country has been overlooked for a long time. The native subspecies $C$. sanguinea subsp. sanguinea is reliably distinguished from the alien subspecies by the hairiness of the lower surface of the leaves. The leaves of $C$. sanguinea subsp. sanguinea are covered with long, erect or decumbent hairs, while $C$. sanguinea subsp. australis are covered with short medifixed hairs, appressed to the leaf surface (Verloove, 2011; SchUlz, 2012).

The current distribution and abundance of C. sanguinea subsp. australis in Lithuania and Latvia indicate that this subspecies is spreading rapidly far beyond its initial sites of introduction and that the process of dispersal has been ongoing for decades. In other countries, $C$. sanguinea subsp. australis has been observed to have become an invasive plant and is particularly frequent in woodlands of urbanised areas (Gregor \& KASPEREK, 2021). We assume that the most critical vector of $C$. sanguinea subsp. australis dispersal is frugivorous birds (Sмітн et al., 2013). Large thickets found under power lines suggests that their seeds are carried by birds that frequently perch on transmission lines to rest.

Further detailed studies on the distribution of C. sanguinea subsp. australis and its impact on plant communities and habitats are needed. It is also essential to assess whether this alien subspecies affects the stability of populations of the native $C$. sanguinea subsp. sanguinea.

Studies have confirmed that C. alba and C. seri$c e a$, two related species originating from different continents, grow in Lithuania. These two species have previously been treated in the broad sense as C. alba s. 1. (GuDŽINSKAS et al., 2017). Therefore, it is necessary to conduct detailed surveys to assess the actual distribution of $C$. alba s. str. and C. sericea in Lithuania and determine their ecological preferences and environmental impacts. However, it is already evident that both species are widespread and continue to spread due to intensive seed dispersal by frugivorous birds (Sмiтh et al., 2013). Most concerning is that both species are invading not only in anthropogenic, but also in seminatural habitats and even in wetland habitats, which have been considered the most resilient habitats to invasion by alien plant species (GuDŽINSKAS et al., 2014).

The generalised results of this and previous surveys show that five alien species of the genus Cornus (C. alba, C. alternifolia, C. amomum, C. mas and C. sericea) occur in Lithuania. Cornus sanguinea is represented by two subspecies: the native $C$. sanguinea subsp. sanguinea and the alien $C$. sanguinea subsp. australis. The three alien taxa (C. alba, C. sanguinea subsp. australis and $C$. sericea) have naturalised in Lithuania, spread rapidly and show signs of invasiveness. In comparison, the other three taxa (C. alternifolia, C. amomum and C. mas) are casual, but can naturalise and spread in the future. In Latvia, two alien species of the genus Cornus (C. alba and C. sericea) and an alien subspecies of $C$. sanguinea (C. sanguinea subsp. australis) have been recorded, while $C$. sanguinea subsp. sanguinea and $C$. suecica are native. Plants of all three alien taxa are naturalised and spread in Latvia. Considering the diversity of plants of the genus Cornus cultivated in Lithuania and Latvia and the fact that birds disperse the seeds of these plants, it can be predicted that in the future, the number of alien species will increase in both countries.

\section{REFERENCES}

Acharya S.N., Chu C.B., Hermesh R., Schaalje G.B., 1992: Factors affecting red-osier dogwood seed germination. - Canadian Journal of Botany, 70(5): 1012-1016.

BaČIČ T., Strgulc-KrajšeK S., Jogan N., 2015: Sivi dren (Cornus sericea L.) - nova invazivna vrsta v flori Slovenije. - Acta Biologica Slovenica, 58: $13-21$.

Caudullo G., Welk E., San-Miguel-Ayanz J., 2017: Chorological maps for the main European woody species. - Data in Brief, 12: 662-666. https://doi.org/10.1016/j.dib.2017.05.007 
Charles-Dominique T., Edelin C., Bouchard A., 2010: Architectural strategies of Cornus sericea, a native but invasiveshrub ofSouthernQuebec, Canada, underanopen oraclosed canopy.-Annals ofBotany, 105(2):205-220. https://dx.doi.org/10.1093/aob/mcp273

EBInger J.E., McClain W., 1997: Recent exotic woody plant introduction into the Illinois flora. - In: Proceedings of the 15th North American Prairie Conference: 55-58. - Bend.

Essl F., Bacher S., Genovesi P., Hulme P.E., JeSChKe J.M., Katsanevakis S., Kowarik I., Kühn I., Pyšek P., Rabitsch W., Schindler S., van KleUnen M., Vilì M., Wilson J.R., Richardson D.M., 2018: Which taxa are alien? Criteria, applications, and uncertainties. - Bioscience 68(7): 496-509. https://doi.org/10.1093/biosci/biy057

Eyde R.H., 1988: Comprehending Cornus: puzzles and progress in the systematics of the dogwoods. - Botanical Review, 54: 233-351.

Ferus P., HoŤKa P., Košútová D., KonôPková J., 2020: Invasions of alien woody plant taxa across a cluster of villages neighbouring the Mlyňany Arboretum (SW Slovakia). - Folia Oecologica, 47(2): 121-130. https://doi.org/10.2478/foecol-2020-0014

Finch D.M., Butler J.L, Runyon J.B., Fettig C.J., Kilkenny F.F., Jose S., Frankel S.J., Cushman S.A., Сobb R.C., Dukes J.S., Hicke J.A., Amelon S.K., 2021: Effects of climate change on invasive species. - In: Poland T.M., Patel-Weynand T., Finch D.M., Miniat C.F., Hayes D.C., Lopez V.M. (eds), Invasive Species in Forests and Rangelands of the United States: 57-83. - Cham. https://doi.org/10.1007/978-3-030-45367-1_4

Gederaas L., Moen T.L., Skjelseth S., Larsen L.K. (eds), 2012: Alien species in Norway with the Norwegian Black List 2012. - Trondheim.

Gregor T., Kasperek G., 2021: Non-native woody plant species in urban forests of Frankfurt/ Main (Germany). - Tuexenia, 41: 133-145. https://doi.org/10.14471/2020.41.001

GudžInskas Z., Petrulaitis L., Arlikevičiūté L., 2014 : Vaccinium macrocarpon - a new alien plant species in Lithuania. - Botanica Lithuanica, 20(1): 41-45. https://doi.org/10.2478/botlit-2014-0005

GudžInskas Z., Petrulaitis L., ŽalneravičIus E., 2017: New woody alien plant species recorded in Lithuania. - Botanica Lithuanica, 23(2): 153-168. https://doi.org/10.1515/botlit-2017-0017
JanuŠKeVičius L., Baronienė V., Liagienė D., 2006: Sumedejusių augalų introdukcija ir aklimatizacija bei jų rezultatai ir perspektyvos Lietuvoje. - Kaunas.

Kaplan Z., Danihelka J., Chrtek J.Jr., ZÁzvorka J., Koutecký P., Ekrt L., Řepka R., ŠtěPÁnková J., Jelínek B., Grulich V., Prančl J., Wild J., 2019: Distributions of vascular plants in the Czech Republic. Part 8. - Preslia, 91: 257-368. https://doi.org/10.23855/preslia.2019.257

Kelly D.L., 1990: Cornus sericea L. in Ireland: an incipient weed of wetlands. - Watsonia, 18: 33-36.

KowARIK I., 1995: Time lags in biological invasions with regard to the success and failure of alien species. In: Kowarik I., Pyšek P., Prach K., Rejmánek M., WADE M. (eds), Plant invasions: general aspects and special problems: 15-38. - Amsterdam.

KřIVÁNEK M., PYŠEK P., 2008: Forestry and horticulture as pathways of plant invasions: a database of alien woody plants in the Czech Republic. - In: ToKARska-Guzik B., Brock J.H., Brundu G., Child L.E., DAehler C.C., PyšeK P. (eds), Plant invasions: Human perception, ecological impacts and management: 21-38. - Leiden.

Laivin̦š M., Bice M., Krampis I., Knape Dz., Šmite D., Šulcs V., 2009: Latvijas kokaugu atlants. Atlas of Latvian Woody Plants. - Rīga.

LekAViČIUs A., 1976: Cornaceae. - In: NAtKeViČAitéIVANAUSKIENĖ M. (ed.), Lietuvos TSR flora, 5: 1521. - Vilnius.

Lindelof K., Lindo J.A., Zhou W., Ji X., Xiang Q.Y., 2020: Phylogenomics, biogeography, and evolution of the blue-or white-fruited dogwoods (Cornus). Insights into morphological and ecological niche divergence following intercontinental geographic isolation. - Journal of Systematics and Evolution, 58(5): 604-645. https://doi.org/10.1111/jse.12676

Maes B., van Loon R., 2020: Wilde en niet-wilde bomen en struiken in vegetatieopnamen. Een voorstel voor een methode van specifieke notering van bomen en struiken in vegetatieopnamen en overwegingen daarbij. - Stratiotes, 55: 19-31.

Marazzi B., Rosselli A., Galasso G., Eggenberg S., 2021: Juglans ailantifolia. A new alien walnut tree species naturalized in Switzerland and Italy. - Bollettino della Società Ticinese di Scienze Naturali, 109: 57-68.

Medvecká J., Kliment J., Májeková J., Halada L., Za- 
Liberová M., Gojdičová E., Feráková V., JarolíMEK I., 2012: Inventory of the alien flora of Slovakia. - Preslia, 84: 257-309.

Murrell Z.E., 1993: Phylogenetic relationships in Cornus (Cornaceae). - Systematic Botany, 18: 469495.

Murrell Z.E., Poindexter D.B., 2016: Cornaceae. - In: Flora of North America North of Mexico. Magnoliophyta: Vitaceae to Garryaceae, 12: 443-457. Oxford-New York.

Navasaitis M., 2008: Dendrologija. - Vilnius.

Navasaitis M., Ozolinčius R., Smaliukas D., BalevičieNĖ J., 2003: Lietuvos dendroflora. - Kaunas.

Nunez-Mir G.C., Guo Q., ReJMÁneK M., IANNONE III B.V., FEI S., 2019: Predicting invasiveness of exotic woody species using a traitsbased framework. - Ecology, 100(10): e02797. https://doi.org/10.1002/ecy.2797

Pergl J., Sádlo J., Petřík P., Danihelka J., Chrtek J.Jr., Hejda M., Moravcová L., Perglová I., ŠtajeroVÁ K., PYŠEK P., 2016: Dark side of the fence: ornamental plants as a source for spontaneous flora of the Czech Republic. - Preslia, 88: 163-184.

Petrulaitis L., GudžInskas Z., 2020: The first records of two alien woody species, Cornus alternifolia and Cornus amomum, in Lithuania. - BioInvasions Records, 9(2): 384-392. https://doi.org/10.3391/bir.2020.9.2.24

Priedītis N., 2014: Latvijas augi. - Rīga.

Pyšek P., SÁdlo J., MandáK B., 2002: Catalogue of alien plants of the Czech Republic. - Preslia, 74: 97-186.

Richardson D.M., Hui C., Nunez M.A., Pauchard A., 2014: Tree invasions: patterns, processes, challenges andopportunities.-Biological Invasions, 16:473-481. https://doi.org/10.1007/s10530-013-0606-9

Riebl R., Meve U., Aas G., 2017: Morphologische Variabilität und taxonomische Differenzierung von
Cornus sanguinea: Nordbayerische Naturstandorte und Straßenbegleitgrün im Vergleich. - Berichte der Bayerischen Botanischen Gesellschaft, 87: 39-54.

Schulz B., 2012: Die Gattung Cornus (Cornaceae), Hartriegel und Kornelkirsche, Teil 3. - Mitteilungen der Deutschen Dendrologischen Gesellschaft, 97: 91-132.

Smith S.B., DeSando S.A., Pagano T., 2013: The value of native and invasive fruit-bearing shrubs for migrating songbirds. - Northeastern Naturalist, 20: 171-184. https://doi.org/10.1656/045.020.0114.

Taura L., GudžInsKas Z., 2020: Life stages and demography of invasive shrub Cytisus scoparius (Fabaceae) in Lithuania. - Botanica, 26(1): 1-14. https://doi.org/10.2478/botlit-2020-0001

Tyler T., Karlsson T., Milberg P., Sahlin U., SunDBERG S., 2015: Invasive plant species in the Swedish flora: developing criteria and definitions, and assessing the invasiveness of individual taxa. - Nordic Journal of Botany, 33(3): 300-317. https://doi.org/10.1111/njb.00773

Verloove F., 2011: Fraxinus pennsylvanica, Pterocarya fraxinifolia en andere opmerkelijke uitheemse rivierbegeleiders in België en NW-Frankrijk. - Dumortiera, 99: 1-10.

WeAKLeY A.S., 2020: Flora of the Southeastern United States. - Chapel Hill.

Xiang Q.Y., Thomas D.T., Zhang W., Manchester S.R., Murrell Z., 2006: Species level phylogeny of the genus Cornus (Cornaceae) based on molecular and morphological evidence - implications for taxonomy and Tertiary intercontinental migration. - Taxon, 55(1): 9-30. https://doi.org/10.2307/25065525

Zwiener V.P., Lira-Noriega A., Grady C.J., Padial A.A., VitulE J.R.S., 2018: Climate change as a driver of biotic homogenization of woody plants in the Atlantic Forest.Global Ecology and Biogeography, 27(3): 298-309. https://doi.org/10.1111/geb.12695 


\section{NAUJI SVETIMŽEMIAI CORNUS (CORNACEAE) GENTIES TAKSONAI LIETUVOJE IR LATVIJOJE}

\section{Zigmantas Gudžinskas, Lukas Petrulaitis}

\section{Santrauka}

Sedulos (Cornus) genties augalai vertinami dèl dekoratyvinių savybių ir dažnai auginami soduose, parkuose arba kituose visuomeniniuose želdiniuose, naudojami apsauginèms juostoms formuoti. Kai introdukuoti augalai plačiai paplinta kultūriniuose želdynuose, labai padidejja tikimybė jiems sulaukèti. Ypač lengvai sulaukèja ir ị antropogenines, natūralias ar pusiau natūralias buveines skverbiasi sultingus vaisius turintys, paukščių platinami augalai.

Straipsnyje pateikiama informacija apie $2021 \mathrm{~m}$. pirmą kartą Lietuvoje dviejose vietovèse (Vilniuje ir Kauno r.) aptiktą sulaukèjusią geltonają sedulą (Cornus mas). Dabar šios rūšies augalai šalyje turètų būti priskirti prie neịsitvirtinusių rūšių grupès, tačiau ateityje jie turi galimybę natūralizuotis. Nepaisant to, yra ypač maža tikimybè, $\operatorname{kad} C$. mas ateityje Lietuvoje galètų tapti invazine rūšimi, todèl šiuos dekoratyvinius medelius galima būtų dažniau sodinti miestų ir gyvenviečių želdynuose vietoje potencialiai invazinių medžių ir krūmų.

Atlikus tyrimus buvo patvirtinta, kad palaipinè sedula (C. sericea) Lietuvoje jau dabar yra plačiai paplitusi, o seniausias šios rūšies herbariumo pavyzdys buvo surinktas 1997 m., Žuvinto ežero pakrančių nendrynuose (Alytaus r.). Cornus sericea, kaip ir baltoji sedula (C. alba), Lietuvoje yra natūralizavusi ir potencialiai invazinè rūšis.

Lietuvoje ir Latvijoje savaime paplitusi raudonoji sedula (C. sanguinea). Vietiniai šios rūšies augalai priskiriami prie raudonosios sedulos tipinio porūšio (C. sanguinea subsp. sanguinea). Atlikus tyrimus paaiškèjo, kad abiejose šalyse plinta svetimžemis, iš Pietryčių Europos ir Vakarų Azijos kilęs raudonosios sedulos pietinis porūšis (C. sanguinea subsp. australis). Remiantis turimais duomenimis, abiejose šalyse šio porūšio augalai jau yra natūralizavęsi. İvertinus šio porūšio augalų gausumą Šiaulių, Kaišiadorių ir Vievio apylinkèse, galima daryti išvadą, kad jis Lietuvoje gali tapti invaziniu augalu. Cornus sanguinea subsp. australis sèklas labiausiai platina vaisius lesantys paukščiai. Straipsnyje aptariami trijų Cornus genties taksonų plitimo vektoriai, nagrinéjamos jų užimamos buveinès, įvertintos jų tolesnio plitimo galimybès. 


\section{APPENDIX}

List of selected specimens of the studied Cornus taxa

\section{Cornus mas $\mathrm{L}$.}

Lithuania, Vilnius, Rokantiškès, at Pupojai str., in mixed anthropogenic woodland, relatively abundant, ca. 50 individuals, 8 August 2021, leg. et det. Z. Gudžinskas. $54.70825^{\circ} \mathrm{N}, 25.36928^{\circ} \mathrm{E}$ (BILAS).

Lithuania, Kaunas district, $8 \mathrm{~km}$ northeast of Lapès, Andruškoniai village, in an abandoned grassland by the willow shrub stand, five individuals, 3 September 2021, leg. et det. Z. Gudžinskas. $55.01784^{\circ} \mathrm{N}, 24.10246^{\circ} \mathrm{E}$ (BILAS).

Cornus sanguinea L. subsp. australis (C.A.Mey.) Jáv.

Lithuania, Elektrènai district, 1,2 $\mathrm{km}$ east of Vievis, environs of Balceriškès village, at the railway, on the edge of anthropogenic woodland, $2 \mathrm{Au}-$ gust 2018 , leg. et det. Z. Gudžinskas. $54.77109^{\circ} \mathrm{N}$, $24.83724^{\circ} \mathrm{E}$ (BILAS).

Lithuania, Panevėžys district, environs of Spirakiai village, in a forest on the western side of the narrow gauge railway line Panevėžys-Joniškèlis, ca. $4 \mathrm{~km}$ from Spirakiai and $4 \mathrm{~km}$ north of Bernatoniai railway station, 26 July 1940, leg. P. Snarskis (determined as Cornus sanguinea L.), det. Z. Gudžinskas (BILAS).

Latvia, Salaspils municipality, $1 \mathrm{~km}$ South of Salaspils, at the Maskavas Road (road A6), in abandoned cultivated grasslands invaded by Solidago canadensis, 1 September 2018, leg. et det. Z. Gudžinskas. $56.84848^{\circ} \mathrm{N}, 24.35357^{\circ} \mathrm{E}$ (BILAS).

Latvia, Bauska municipality, $1.5 \mathrm{~km}$ north of Dālini village, on the edge of woodland near the road, large thickets, 19 July 2019, leg. et det. Z. Gudžinskas and L. Petrulaitis. $56.528860^{\circ} \mathrm{N}, 24.17014^{\circ} \mathrm{E}$ (BILAS).

Latvia, Tukums, southwestern part of the city, industrial district, on the slope of a ditch near the railway line, 20 July 2019, leg. et det. Z. Gudžinskas and L. Petrulaitis. $56.95680^{\circ} \mathrm{N}, 23.12075^{\circ} \mathrm{E}$ (BILAS).

\section{Cornus sericea $\mathbf{L}$.}

Lithuania, Alytus district, environs of Simnas, the eastern part of Žuvintas Strict Nature Reserve, on the shore of Lake Žuvintas, in a reedbed, 14 August 1997, leg. et det. A. Balsevičius (BILAS). 